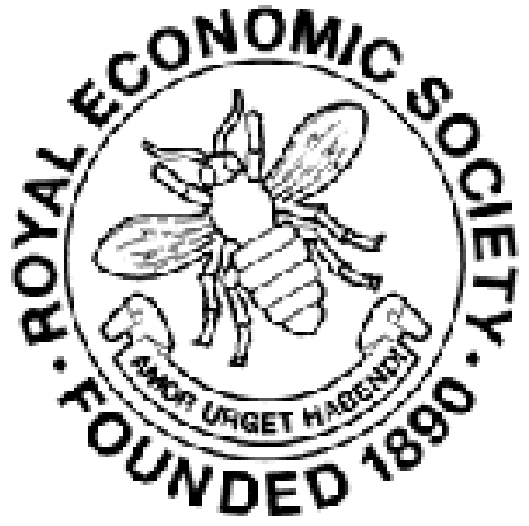

The Minimum Wage Law in Victoria and South Australia

Author(s): W. P. Reeves

Source: The Economic Journal, Vol. 11, No. 43 (Sep., 1901), pp. 334-344

Published by: Wiley on behalf of the Royal Economic Society

Stable URL: http://www.jstor.org/stable/2956666

Accessed: 20-04-2016 01:36 UTC

Your use of the JSTOR archive indicates your acceptance of the Terms \& Conditions of Use, available at

http://about.jstor.org/terms

JSTOR is a not-for-profit service that helps scholars, researchers, and students discover, use, and build upon a wide range of content in a trusted digital archive. We use information technology and tools to increase productivity and facilitate new forms of scholarship. For more information about JSTOR, please contact support@jstor.org.

Royal Economic Society, Wiley are collaborating with JSTOR to digitize, preserve and extend access to The Economic Journal 


\section{THE MINIMUM WAGE LAW IN VICTORIA AND SOUTH AUSTRALIA.}

WHen the last mail for England left Melbourne a Royal Commission had been for some time sitting to inquire into the working of the Shops and Factories law of 1896. Some of the evidence given before it had been hostile to the law, as might have been expected. Paragraphs have appeared in more than one well-known London newspaper suggesting that the Act has caused and is causing friction, and has even led, in one case, to a suspension of industry. A set of indignant masters are said to have shut up their works. Without denying that the law has been and is hotly criticised in the colony, and without suggesting that it has yet emerged from the stage of experiment, I will point out that Victorian manufactures have managed to thrive under it, and to regain the place which they held in 1890, but lost so lamentably after the banking panic and the collapse of what is commonly called the Melbourne land boom. In 1890, when Victoria was enjoying the inflated prosperity for which she afterwards had to pay dearly, the number of hands employed in the colony's factories was 47,813. In 1894, with commerce in the trough of the depression, this number sank to 34,268. In 1900 it had risen to 52,898 . Whatever, therefore, the minimum wage law may have done, during the four years in which it has been applied, it has not been generally ruinous or terrifying.

The Factories and Shops law of 1896, under which legal minimum wages were for the first time fixed, was one of a series of factory laws the first of which was a little statute passed in 1873. This, the pioneer of its race in Australia, laid down that 110 girl or woman should work for hire in a factory for more than eight hours daily.

The next step forward was taken by a second law, that of 1885. This was the outcome of the plain-spoken report of a Royal Commission which had sat in the year before to inquire into 
alleged sweating. By the law of 1885 the number of persons needed to form a legal factory, which had hitherto been ten, was reduced to six including apprentices, and employers were ordered to keep a record of outwork. The best parts of the law of 1885 were those enforcing cleanliness, air space, the requirements of decency, and the fencing of machinery. Under these clauses much good work was done by the government inspectors. As Melbourne and he other towns grew larger and were better built, hundreds of dilapidated old buildings were pulled down and replaced by better factories. The inspectors saw to it that the arrangements in them were good. How unsatisfactory the condition of numbers of factory and shop workers remained in many other respects, and how miserable was the lot of the sweated out-workers, the reader may learn from official reports and from the columns of the Age and Argus newspapers.

For ten years there was little or no change in the law. Not until 1895 was any real step forward taken. In that year the number of hands necessary to constitute a legal factory was reduced from six to four; but by that time, thanks to the revelations brought about by anti-sweating agitation, public feeling was thoroughly roused; the principle of a fixed minimum wage, which should be a living wage, had been adopted both by a resolution of the Lower House of Parliament dealing with government workpeople and by the Metropolitan Board of Works for Melbourne, and the Act of 1895 was not accepted even as a stop-gap. A far bolder and more thoroughgoing measure was drafted by Mr. Peacock, now Prime Minister of the colony, and after a sharp struggle with the Legislative Council, became law on the 1st October, 1896. In no other colony, at any rate at that time, could such a measure have become law, and only the Melbourne newspapers' courageous exposure of the sweating that had been going on year after year in that city and elsewhere in Victoria, confirmed by the evidence given before a board of inquiry in 1893 and backed by the agitation of the Victorian Anti-sweating League, could have formed a public opinion ready to accept so strange and novel an experiment. Venturesome and full of new features the measure indeed was. Most students of labour problems have by this time heard of one feature-the wages boards. But the interest of the Shops and Factories Act of 1896 is by no means confined to these. It introduced changes so many and so vital, and marks such a striking departure in the history of Australian industrial law-making that I make no apology for quoting here certain parts of the official summary of its chief clauses prepared 
by the Victorian factories department. These all relate to factories. The portion of the law relating to shops will not be touched on in this article.

Every place in which furniture is manufactured was made a factory or work-room.

Every place in which a Chinese person is engaged in laundry work wäs made a factory or work-room.

Laundries in which four persons are employed were made factories or work-rooms, excepting only laundries carried on by charitable institutions.

Power to extend the operations of the factories portions of the Acts to shires was given to the Governor in Council.

Every person making clothing or wearing apparel (including boots and shoes) for trade or sale outside a factory or workroom, was required to send his or her name and address to the Chief Inspector of Factories.

Provision was made for the appointment of special boards to fix the lowest price or wage to be paid for making any article of clothing or wearing apparel (including boots and shoes), furniture, and for bread making or baking.

Excepting the furniture board, which was to be appointed by the Governor in Council, such boards were to be elected by the employers and employés engaged in the manufacture of the articles for making which the board is to fix the price. In default of such election, the Governor in Council was to appoint the members of the board. Each board was required to elect a chairman (not a member) within fourteen days, and if this was not done the Governor in Council was to appoint a chairman. A short amending act was passed late in the year for the purpose of meeting a difficulty which had arisen in connection with the special board to be appointed to fix the price for making furniture. It was found that the Chinese could have elected the whole or a large majority of the representatives on such board, and parliament then decided that in the case of furniture the board should be appointed by the Governor in Council.

No person was to be employed in a factory or work-room unless in receipt of a weekly wage of not less than $2 s .6 d$.

Inspectors were given the power to prosecute the occupier of a factory or work-room in an insanitary condition.

The Chief Inspector of factories was given power to condemn any factory or work-room which was in his opinion dilapidated, unsafe, unfit for use, \&c., and within two months of the date of the notice the occupier was required to obtain the local council's 
written consent to the continued use of such premises as a factory.

No portion of a factory or work-room could be used as a sleeping place unless such sleeping place is separated from the factory or work-room by a substantial wooden partition extending from floor to ceiling.

No female whosoever, and no boy under sixteen years of age, could be employed in a factory for more than ten hours in any day or after nine o'clock at night (this provision is in addition to the Act of 1885, which provides only that such persons could not be employed for more than 48 hours in any week); on ten days in any calendar year overtime might be worked to the extent of six hours if notice within 24 hours was forwarded to the Chief Inspector and overtime and tea money paid.

In any factory in which furniture is made no person was to work before half-past seven in the morning or after five o'clock in the evening, or on Saturday after two o'clock, or on Sunday at any time whatever; and the same hours apply to any laundry in which a Chinese person is working.

Provision was made for the stamping of all furniture made in Victoria with the maker's name and address, and whether made by Chinese or European labour.

All persons in charge of boilers and steam-engines must henceforth hold certificates of competency.

Important as many of these changes will at once seem to the student of factory laws none of them vie in interest with the remarkable experiment of appointing boards to fix wages. The first batch of these novel bodies was six in number. They were constituted and went to work early in 1897. Five of the six were elected, and the sixth nominated by the Governor in Council. Each consisted of ten members, five for the employers and five for the workpeople; and of a chairman, presumably impartial. The six trades to be regulated were:-

Elected Boards $\left\{\begin{array}{l}\text { Baking. } \\ \text { Men's and Boys' Clothing. } \\ \text { Bootmaking. } \\ \text { Shirtmaking. } \\ \text { Under Clothing. }\end{array}\right.$

Nominated Board : Furniture.

The function of these boards was to fix the wages paid to time-workers, and, if possible, the rates for piece-work; also to regulate the proportionate number of apprentices and improvers.

No. 43.- - VOL. XI.

A A 
This duty they all endeavoured to discharge, with, as might be expected, unequal success, especially in their earlier efforts. The baking board, for instance, met with little trouble. They had the good fortune to secure as chairman, a judge, Sir Hartley Williams. As no piece-work was done amongst the bakers they were saved from a common cause of complication. By raising the pay of men to a shilling an hour, and fixing the apprentices' minimum at five shillings a week, they gave, it was reckoned, an immediate increase of 25 per cent. to the adults in their trade. Country bakeries were not affected by their "determination." Nevertheless the average weekly wage paid to men and boys in the trade throughout the colony was raised from $£ 112 s .5 d$. for the year 1896 to $£ 21 s .6 d$. for 1898 , and to $£ 21 s$. $10 d$. for 1899 . In other words the average gain for every worker was $9 s .5 d$. a week, though the gain to the men was, of course, more, and to the boys less, than the average. As the law also limited the working hours to forty-eight weekly the fortunate bakers got much more pay for much less work. Yet very little friction seems to have been caused by the change which, in practice, was neither ruinous to employers nor inconvenient to the public.

With the clothing trade board matters did not run quite so smoothly. So minute and elaborate was its "determination" that it took nine months to draw it up, and its details filled thirty-five pages of closely-printed foolscap. The minimum wage for men was fixed at $7 s .6 d$. a day; that of women at $3 s .4 d$. a day, or $£ 1$ a week. To earn this a workwoman had to be skilled, i.e., must have served five years at her trade. An exhaustive schedule of piece-rates was also issued. They were fixed so as to be a little higher than the time-rates in order that the homeworkers might have something to meet the cost of sending work to and from the factory, firing, and other small charges. This benevolent effort to help the outworkers was promptly checkmated by the employers, who, finding they could get work done cheaper by the time-workers in the factories, ceased to give it out. The more fortunate of the piece-workers were taken on as factory hands at the new and improved wage. Most of the others lost their work altogether. Moreover, while the board had been digesting its determination the employers had had nine months in which to accumulate heavy stocks made at the old low rates of pay. This they had done without remorse or ruth, and a corresponding time of slackness followed the proclamation of the new rates, the blame of which was, of course, laid on the increased scale of wages. The board, too, had limited the number of apprentices 
and improvers ; the proportion was not to exceed one apprentice to every three tailoresses, and the children were to be paid. They were to get half-a-crown in their first year, rising annually to fifteen shillings in their fifth year. A sharp reduction in the number employed was the not unnatural result. The employers complained that they were not allowed to have enough of them to fill vacancies amongst adults. In 1899, however, it was shown that the masters were not employing as many as the Act permitted. Of course, their real objection was to the new scale of pay.

The clothing board, however, stuck to its determination and gradually the disturbance settled down. More piece-workers entered the factories, and the hard case of a few old and needy folks who were not worth the legal wage was met by allowing them to work for less than the minimum rate. The number of hands in the trade, which fell in 1898, more than regained the lost ground in the next year. By the end of 1899 there was not much grumbling except at the scarcity of apprentices. The average rate of remuneration had increased in the case of men and boys from $₫ 115 s$. $3 d$. a week to $£ 119 s$. $5 d$. Amongst the women and girls it had gone up from 15s. $5 d$. to 18s. $6 d$.

Like the clothing board the boot-making board made a bad start. It had, too, a troublesome trade to deal with. Bootmanufacturing in Victoria had been overdone by small employers. Then had come the importation of new machinery capable of supplying a far larger market than the Australian. The whole of 1896 was passed by the board in trying to fix a determination which should not be bitterly objected to either by masters or men. Its first proposal was so strongly protested against by the masters that it was withdrawn. A lowered minimum met the same fate at the hands of the men. A compromise pleased neither side, and left the piece-rate so much higher than the time-wage that the story already told in the case of the clothing determination may stand for the effect of that in boot-making. To make matters worse came a rise in the price of leather which hit the manufacturers rather hard. However, the average increase in wages to hands of all ages employed in the trade was in 1889 $4 s$. $8 d$. a head. The gain to adults was, therefore, a good deal more. Oddly enough, the number of young girls apprenticed was growing greater. The cost of boots and shoes to the public had not risen.

The shirt-making board went to work with caution and did not arrive at a determination until January 1898. Nor did it, A A 2 
even then, attempt any heroic measures in dealing with its badly sweated trade. It was content to stipulate for a minimum of $4 d$. an hour for the women in the factories,-there were scarcely any men working in the trade. As 48 hours was the legal week this only amounted to a wage of sixteen shillings weekly. Piecework rates corresponded. Yet this modest pay meant an average gain of $11 d$. a week all round and of more than that to the grown-up workers. Little or no disturbance followed the determination.

The first under-clothing board met even greater difficulties at the outset than even the bootmaking board. It failed altogether to fix prices, and resigned. A second board, appointed in 1898, made headway, though slowly; and, at last, in the middle of 1899, a determination came into force. The trade, which included the making of such articles as pillow-slips, aprons, and pinafores, had been in a wretched condition and was looked upon amongst needlewomen as little better than a refuge for the destitute. As late as 1898 the average weekly earnings were $11 s$. $3 d$., and there were workers who had been five or six years in the trade and were fairly quick with the needle who were making but twopence an hour. The board fixed the time-wage at the same figure as in shirtmaking, namely $4 d$. an hour. This in the factories, where forty-eight hours were the legal week, meant 16s. for the six days' work. It was found almost impossible to fix satisfactory piece-work rates owing to the variety of the work and the continual change of designs and patterns. Two apprentices were allowed to each skilled worker or improver, and though the full number were not taken on, there were about as many apprentices as workwomen in 1898. The weekly average of pay all round was only $12 s .6 d$. Still, this was a rise of fifteenpence, and one or two of the workwoman's smaller troubles, such as having to pay for her cotton, had also been remedied.

The furniture-making board's first determination was gazetted in April, 1897, and was revised in October, 1898. In the second edition the pay of men was fixed at a shilling an hour, and that of women at fivepence an hour. The former could thus earn eight shillings and the latter $3 s .4 d$. in a legal factory day. This was a gain of $6 s .9 d$. a week all round, but of this only $1 s .2 d$. went to women and girls. In the "European" factories,-i.e., where the workpeople were whites-no great difficulty was found in getting the new rates paid. With the Chinese it was otherwise. The masters amongst them at once put most of their men 
secretly on piece-work, and employers and employed laid their heads together to outwit the inspectors. The former, with the most courteous air in the world, would tender pay-sheets which purported to show that their men were getting nearly seven shillings a day all round. The men smilingly acquiesced, and, when inquisitive inspectors pressed them with specific questions about secret piece-rates, they professed ignorance of any such arrangements asseverating that they were paid by time and were getting full wages. To protect workpeople who are being driven into breaking factory laws against their will is not easy. To protect them when they connive at their own oppression is notoriously difficult. When they are Asiatics, speaking an unknown tongue, or knowing but a smattering of English and ready to forget that whenever convenient, they become the despair of the most patient inspector. In this way collusion between masters and men did its best to baffle detection of work done after legal hours. When the inspectors, guided by the sound of tools, entered some Chinese work-room where cabinetmaking was going on after hours they would be met with protestations of innocence from all inmates. Only by many prosecutions was some respect for the law tardily obtained. Still, annoying and baffling as the lying obstinacy of the Chinese was, by the year 1899 the state of the furniture trade was a cheerful contrast to its demoralised condition in 1893. The white workers were no longer sweated, and bitterly as their employers complained of Chinese evasion of the law, business was brisk and they were able to live and carry on.

At the beginning of 1900 the boards and the system of a minimum wage had had three years' trial. They had had to stumble along amid many traps and pitfalls, to deal with a multitude of complicated and puzzling little problems, some of which they had not solved, and they had made more than one mistake. Yet, broadly speaking, they had certainly not failed. In their efforts to reorganise six sweated trades, they had succeeded in four and partially succeeded in the other two. Their blunder in forgetting, at the outset, to make special provision for the old and slow workers in the clothing and underclothing trades,-a blunder which they might have avoided had they watched the methods of the New Zealand Arbitration Court-had been repaired. Though to some extent outmanœuvred by the Chinese in the furniture trade, they had improved even that unfortunate industry. Except, perhaps, in the bootmaking trade, they had 
done very little of which the decent majority of masters could fairly complain. On the contrary they helped the fair employer against the undercutter and the sweater. Prices to the consumer had not been appreciably raised by their reforms; the public therefore had nothing to grumble at. Making full allowance for errors, humanity was the better for what had been done. Real work had been accomplished in a righteous cause, and Victoria had abundant reason to give the great experiment a wider scope and a further trial under amended conditions.

This, accordingly, the Victorian parliament did. In October, 1899, Mr. Peacock introduced a bill to extend the duration and expand the powers of the law of 1896. After some delay, caused by a change of ministry, and a sharp tussle between the two Houses, the bill became a statute, substantially in the form its friends wished. The upper House limited its life to two years plus a session of parliament, and the lower House had already stipulated that a Royal Commission should be appointed to inquire into the effects of factory laws upon trade, manufacture, labour, and commerce. If we may judge by the investigations of former commissions into factory and shop life in Melbourne the reports of this body-which, as mentioned at the outset, is now sitting -is not likely to do much harm to the cause of reform; all earlier reports and evidence have fed the demand for more regulation.

Under the Act as assented to, the butchers and pastrycooks' trades were added to the six trades already subject to the regulation of wages boards. Far more important than this specific extension is the clause under which the Governor in Council is now authorised, on receiving a resolution passed by either House of Parliament, to appoint a special board to fix the minimum of pay and the maximum of hours for any other industry. Some thirty special boards have, I believe, been appointed under this section and more have been asked for. Under another clause boards were also to fix the extra pay to be given for overtime, and-as before-the proportion of apprentices and improvers and their lowest wage. Piece-rates were to be based on timerates but were not to be challenged or invalidated because they were not the precise equivalent of time-rates. The board, after fixing the time-wages for any trade, might, instead of fixing piece-rates itself, leave it to the employer to pay his people a fair equivalent to the legal time-wages. The chief inspector of factories might at any time challenge any rates thus settled by 
the employer and bring them before the board for adjustment. In such case the onus of showing that they were equal in effect to the board's time-wages was to lie on the employer.

No one familiar with the working of the Industrial Conciliation and Arbitration Act of New Zealand can help comparing the extended Victorian law with that. At the first glance the two systems seem unlike; in certain essentials they resemble each other rather closely. Both regulate the conditions of labour though in different degrees. What is most interesting about the comparison is that, different in form as the two laws are, and designed as they seemed to be when first passed to attain different objects, they are, nevertheless, being gradually assimilated under the pressure of practical experience. This is the more noteworthy because they were drafted quite independently, and have, so far, worked on in separation. The New Zealand law was the earlier, but the Victorians borrowed nothing from it; nor in amending and expanding their own statute have the New Zealanders taken anything from Australia. In groping for a way through a difficult thicket two sets of explorers are unconsciously tending to take the same road.

Until the end of the year 1900 the colony of South Australia, radical and progressive as it was in other directions, lagged behind in the regulation of factories and shops. Nothing worth speaking of was done until 1894, and then not very much. Children under thirteen were in that year forbidden to work in factories in Adelaide and its suburbs, and forty-eight hours fixed as the weekly stint of women and boys under sixteen. Overtime, however, might be worked on a hundred days in the year; it took six workpeople to make a factory; and the clauses. inserted to safeguard the health and lives of factory hands were crude and insufficient. Five years experience, the example of other colonies, and in particular the revelations of the Adelaide factory inspectors awakened the South Australian conscience to some purpose. The Factories Amendment Act of December, 1900, not only adopted the Victorian wages board system almost in the words of Mr. Peacock's Act, but contained a definition of "factory" which went far beyond the Victorian. Henceforth in Adelaide the word factory includes any workroom where any one is working in the owner's employ; and though this would still seem to ignore small coteries of outworkers it is a great advance on the older law. Moreover, the lowest wage to be paid to any.one working in a factory was made four shillings a 
week-eighteenpence more than the minimum for the factorychildren in Victoria. Full records of terms and particulars relating both to in and out workers were to be kept. When fixing legal minimum rates any wages board was expressly authorised to allow a special rate in the case of any one who through age or physical infirmity could not get employment at the board's general rate. This humane direction ought to enable wages boards in South Australia to steer clear of the unluckiest of the early mistakes made by the Melbourne boards.

W. P. REEVES 